\title{
The Eloquent Language: Hindustani in 1940s Indian Cinema
}

\section{David Lunn}

King's College London

David Lunn is a Research Associate on the European Research Council project Musical Transitions to European Colonialism in the Eastern Indian Ocean at King's College London. E-mail: david.lunn@kcl.ac.uk

\begin{abstract}
The Hindi-Urdu debate that raged in pre-Independence India was to find a new medium for articulation in the arrival of the talkies - or sound in cinema - in the 1930s. Yet the inclusive register of language most commonly employed in films - both historically and currently suggests that cinema largely sidestepped the vitriol and bright-line divisions that characterised the literary and publishing worlds. This article investigates some of the linguistic strategies employed by scriptwriters, lyricists, and producers in Hindi-Urdu-Hindustani cinema of the 1940s. It examines scripts, lyrics and poetry to explore the (de-)linking of linguistic and religious or class identities; the relationship between poetry and filmic lyrics in the person of the poet-lyricist and in the texture of their presentation; and the potential and limits of this oral/aural medium in the context of its written paratexts. Ultimately, it suggests that cinema afforded an inclusivity with respect to language, allowing for a "crystallisation" of filmi Hindustani, though this was far from a foreordained process.
\end{abstract}

\section{Keywords}

Hindi, Urdu, Hindustani, register, orality, advertising, Paratext, poetry, lyric, texture.

\begin{abstract}
'The curse of Babel,' Sheikh Iftekhar Rasool said laconically, in reply to my question if talkies were likely to take India by storm as effectively as the silent film had done. After a pause, he continued, 'But talkies will grip the imagination of the Indian cinema-goer eventually, when there are talkies in his own tongue. The silent film was a natural development of the charade, and of the dumb show with which anyone who is a stranger in a country and ignorant of the language of the country is familiar. The eloquent language of gesture had the touch which makes all the world akin.' (Roome, 1931)
\end{abstract}

Sheikh Iftekhar Rasool, actor and director of the Elephanta Film Corporation, was addressing perhaps the most significant issue for the Indian film industry of the 1930s. The advent of sound in film and of "talkies", beginning with Ardeshir Irani's 1931 feature Alam Ara (Light of the World), presented a novel dilemma to the producers. As Sandra Freitag has succinctly put it, the introduction of sound;

introduced the complications of language in a way never before encountered, so that filmmakers now found their markets reduced to a tenth of their previous size, while economies of production in a few dispersed centres were fragmented by the need to create films catering to specific regional/linguistic cultural areas. (Freitag, 2001;65)

The multi-lingual nature of India was nothing new, but its intrusion into the world of film was something of a technological double-edged sword, at once opening up the media to exciting, crowd-pleasing and thus potentially lucrative opportunities and innovations, while at the same time forcing producers to consider carefully the language of production and, with this, their intended audience. In the Hindi-Urdu-Hindustani context, this became a question of register, of which range of the oral continuum would be appropriate for a given character, film or 
situation. This article explores some of the choices made in this regard during the early 1940s, charting the variety of styles and registers that were employed in films that are commonly referred to as Hindi Cinema. ${ }^{1}$ Broadly, it argues that this cinema came to embody and employ an expansive and inclusive register of Hindustani as the default medium of communication, in both dialogue and song; that, while differing registers were occasionally used to mark religious identities, there was no imperative to make exclusive communal associations; that elements of script that surrounded individual films - their paratexts - quickly defaulted to Roman script; and that an understanding of this oral/aural extension to the field of cultural production has important perspectives to offer on the Hindi-Urdu debate.

Indeed, the convenient and common designation of "Hindi Films" obscures an important dynamic that I argue lay at the heart of the transition from stage to screen, from silent movies to "talkies", and in both the propagation of these films to a national audience and their imagination as a national industry. I therefore refer to these films as "Hindustani" films chiefly because of the linguistic fluidity that they exhibited and, in many cases, apparently revelled in. While remaining fully aware of the disputed nature of the term in especially literary contexts and debates over the national language question, my own use of this moniker in the cinematic context is not without scholarly precedent: Ashraf Aziz (2003), for example, has consistently applied it to Hindustani film music, suggestively pointing towards the linguistic hybridity and inclusivity that I too believe to be constitutive of the medium. ${ }^{2}$

On a broader scale, the advent of film, and particularly of sound in film, constituted a significant intervention in the dynamics of the Hindi-Urdu public sphere. In the context of the shifting forms of patronage available to litterateurs, which had been in constant flux from the $18^{\text {th }}$ century on, the film industry was a significant new source of employment and of income on a level potentially much greater than that generated by literary production and publication. As such, writers of all stripes were drawn into the ambit of the industry. In the Hindi-Urdu context, this quite naturally involved writers of both Hindi and Urdu literature. Some of the most prominent figures of early $20^{\text {th }}$ century literature were, at one point or another, and for varying lengths of time and to varying degrees, involved in writing for films. Premchand is, perhaps, the most notable example, though his dalliance was emphatically that. Other prominent writers involved include Pandey Bechan Sharma 'Ugra', Krishan Chander, Shakeel Badayuni, Saadat Hasan Manto, and many others. The writing of not only scripts, but also of lyrics, was therefore undertaken by a group of writers who, from the perspective of their literary backgrounds, spanned the Hindi-Urdu divide.

Moreover, these writers were writing in and for a profoundly different media, with significant implications for the way language was consumed. Orality/aurality was becoming the defining feature of the filmic medium (George, 2011), and this same feature represented a potentially ground breaking innovation in the context of the Hindi-Urdu debate. At a time when language was being increasingly defined by script, and when script was increasingly associated in conflicting and competing nationalisms with exclusive and bounded religious identities, this oral medium allowed at the very least for the divorce of language from its written form, and potentially for the development and even crystallisation (as opposed to formalisation or standardisation) of a neutral, unmarked register of Hindustani. By crystallisation, I mean a process that was informal, unforced, unofficial, and perhaps even organic. It is in many ways the direct opposite of the formal, literary-institutional attempts to create, control, or police language and its use, such as those of the Hindi Sahitya Sammelan or Hindustani Academy. Indeed, it is the very novelty of the film industry, its relative freedom from direct interventions on the part of the established literary critics (though not that of other commentators), and perhaps its location in Bombay and at a distance from the intense language politics of the Hindi heartland, that allowed for the development of conditions of linguistic and creative experimentation and fluidity. ${ }^{3}$

Yet this rather utopian trajectory was complicated by two significant factors: firstly, there were of course textual frames in and through which the films were situated and marketed; secondly, there were plenty of occasions on which religious identities were marked and language associations reified through the subtleties and complexities of language use. Thus, while I argue that Hindustani Film was the site wherein Hindustani as a common register did 
in fact flourish in the pre-independence period, and moreover that the label of "Hindustani Film" is intrinsically more appropriate and accommodating than "Hindi Film" in both the preand post-independence periods, the evolution of this filmic language was neither linear nor inevitable. ${ }^{4}$

I begin by examining the various ways in which register was employed to mark identities, both contemporary and historical/imagined, suggesting that while these variations in register often served to mark out religious differences, they were just as readily used to mark differences in class and education levels, as well as being deployed for entertaining purposes. Therefore the Hindustani film came to contain these various registers, rather than necessitating a choice between them. The same is true of the song lyric. Here we can note the moments of assonance and dissonance between these film $\bar{\imath}$ git and the written, published poetry these film lyricists also produced. The wide range of registers employed by individual writers, and not uncommonly within individual films, is suggestive of both their own versatility, and of the broad continuum in which they felt the film could operate. I also show how certain discontinuities between a lyricist's work in films and his published poetry demonstrate a kind of slippage between the two media, while also strengthening the case for a crystallisation of an accommodating brand of Hindustani within the film industry. I also consider how issues of language use and register interacted with film thematics and subject matter, offering fresh perspectives on issues of communal harmony and national unity as performed in an unnamed, but unmistakably inclusive, film $\bar{\imath}$ Hindustani language. Finally, I acknowledge and investigate the limits of this filmic orality through the paratexts that were produced around the films themselves, demonstrating how the framing of films by credits, titles, and adverts reveals a strategic openness and inclusivity concerning issues of language and script across the board. Fundamentally, I argue that it was in and through this oral/aural medium that the filmic Hindustani with which we are so familiar today became concrete, and established, albeit largely unwritten.

\section{Marking Identities? The Multiple Uses of Register}

Even within the context of what I am arguing was a broad and inclusive use of an accommodating register of Hindustani in the context of films, the use of language in the films themselves could and did mark characters in various, and often subtle, ways. The broad linguistic spectrum of Hindi-Urdu offered abundant potential for this linguistic characterisation, wherein individual characters could speak in a register that marked them out, and distinguished them in some way from other characters not only on the basis of language, but thereby also on bases of religious identity, social class and educational level. However, as the following examples illustrate, different registers worked across these various axes of differentiation in mixed and inconsistent ways, demonstrating a plurality of approaches to the language of film in the late colonial period.

Mehboob's epic historical film Humayun (1945) chronicled the period of the early Mughal emperors Babur (Shah Nawaz) and Humayun (Ashok Kumar). In a film strongly criticised by contemporary members of the Hindu-right, for having created a "myth" of historical HinduMuslim unity (Mukhopadhyay, 2004; 131-2), Mehboob freely employed highly Persianised vocabulary, and indeed Persian itself, in an attempt to depict or evoke the historical reality of the Mughal court. Especially in formal moments, such as the arrival of the emperor in the court (first Babur, later Humayun), a particularly Persianised register emphasises the formality of the occasion, and in occasional short moments Persian itself is employed to address the emperor and the assembled nobility. How can such distinctive interventions be understood in the context of a film that, during a time of intense linguistic antagonism, purported to strive to represent harmonious Hindu-Muslim co-existence? I suggest that we view these moments not as sites of exclusion (as only a very small percentage of the film audience, regardless of religion, would have been fluent or even conversant in Persian in 1945), but as heteroglossic interventions into a monoglossic environment, broadly understood, wherein comprehension and therefore access was relegated to a position of secondary importance behind an almost tangible aural pleasure. A soupçon of Persian may 
well have affected filmgoers in very similar ways to my own use of a French noun in place of its common or garden English alternatives - dash, sprinkling - affects the reader: adding a slight sense of the exotic, or cultured; demonstrating a level of multilingualism and flair; creating a moment of linguistic diversity and variation; or, it must be acknowledged, alienating some by virtue of pretension and inaccessibility. What my own addition does not possess, however, is any claim to representational veracity. The combination of this latter effect with any or several of the above-listed perceptions serves to produce an aural experience that, taken together with the visual spectacle of the court scenes (a spectacle further enhanced, some 15 years later, by the use of colour in several of the court scenes in K.K. Asif's Mughal-e Azam (The Great Mughal)), produces an experience that Mehboob clearly intended to be both spectacular and, if not historically accurate, then at least evocative.

More generally, the characters in Humayun employ a broad range of registers along the Hindi-Urdu spectrum. It is not entirely accurate, however, to suggest that "the dialogues used for Hindu characters were generally in Hindi, while Urdu was used for the spoken parts of Muslim characters." (Mukhopadhyay, 2013; 179-80) Such assertions ignore the intrinsic fluidity to oral, filmic language which, as I have already suggested, facilitated much more expansive individual vocabularies to flourish unmarked by the most compelling visual signifier of difference - that is, script. Setting up an oppositional distinction between Hindu characters speaking "Hindi" and Muslim characters speaking "Urdu" furthermore obscures the subtle, nuanced and diverse ways in which Mehboob and his scriptwriter, Aga Jani Kashmiri, employed the full range of Hindustani often within a single character. The figure of the Rajput prince Randhir Singh (Chandra Mohan) is illustrative in this regard: while he is presumably the Hindu character in whose speech Mukhopadhyay detects "Hindi", and while he does indeed employ slightly more words of Sanskritic origin than his Muslim counterparts in the Mughal court, he is portrayed time and again to be at least as comfortable with a Persianised register as he is with any other, and as comfortable as any of his interlocutors. Consider, for instance, the early dialogue between the Rajput prince and Humayun, when the former bursts in and interrupts Humayun's attempted seduction of Nargis' character, Hamida Bano:

\author{
Randhir: Śăhzāde, talvār lāo. \\ Humayun: Kyom? \\ Randhir: Maim badlā lene āyā hūm. \\ Humayun: Aj̄̄b badmazāq ādmī ho tum. Kitnā acchā mauqā hāth se nikalvā diyā. Jab tak ho talvār \\ hāth meì, badlā lene cale ā rahe haim.

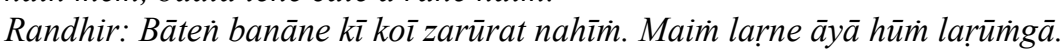 \\ Humayun: Śahzāde is vaqt laṛne ke lie taiyār nahīm. Agar larnā ho, havā se lariye. \\ Randhir: Śahzāde, hoś meì ào. Yah mazāq kā vaqt nahìm. \\ Humayun: Yah mazāq ke lie vaqt o bevaqt kaisāe Aur ab to kumārī bahin ke vajah se riśtā hī aisā \\ qāim ho cukā hai. \\ Randhir: Lekin merī pratijñā pürī hokar rahegī!
}

Randhir: Prince, bring your sword.

Humayun: Why?

Randhir: I have come to take revenge.

Humayun: You are a strange, unfortunate man. You've lost me such a good opportunity. There you are with sword in hand, come to take revenge.

Randhir: There's no need for discussion. I have come to fight, and fight I will.

Humayun: This prince isn't ready to fight just now. If you want to fight, fight the air.

Randhir: Prince, come to your senses. This is not a time for humour.

Humayun: What's this good or bad time for fun? Besides, we have a relationship through your sister the princess.

Randhir: Yet my vow will still remain!

Randhir's one word of distinctly Sanskritic origin - pratijñ $\bar{a}$ - is all that sets his speech apart from his Mughal counterpart, and it is this same kind of sprinkling that occurs time and again throughout the film. 
It is also worth noting that Randhir's ease with the Persianised register of the court is not simply because he is a male member of the Mughal elite, as Veena Kumari's Rajput princess speaks in as Persianised a register as any of her interlocutors, including Babur and the prince Humayun, despite her Hindu identity and gender. Kashmiri's use of language is both playful and inclusive: consider, for instance, the exchange between Veena Kumari and the character of Hamida Bano, the commoner and love interest of Humayun, as they discuss the prospect of the latter's engagement:

\section{Hamida Bano: Āp to śā 'irī farmāne lagĩ? \\ Rajkumari: Jì hāim. Abhī to āp ko manāne ke li'e pūrī kavitā kahnī paregī.}

Hamida Bano: Have you started reciting poetry?

Rajkumari: Yes. Now you too will have to start reciting poetry to win them over.

This exchange, coming immediately after the Rajkumari's recitation of an Urdu śer, perfectly captures the counter-intuitive ways in which Kashmiri played with the registers of Hindustani: first, the formal Urdu śer, with Islamicate religious overtones, from the Rajput princess; then, the commoner offers comment on this newfound interest in reciting poetry, using the formal, Urdu or Persianised muśa 'ira term of śa 'ir $\bar{c}$ farmānā; then the princess affirms the necessity of the recitation of poetry, in the more Indic term kavitā kahna as a sine qua non of courtly life.

Such filmic moments, especially wherein the spectre of the literary comes to the fore, demonstrate the broad linguistic range on which screenwriters felt able to draw. Rather than emphasising dichotomies - Hindi in the mouth of a Hindu character, Urdu in that of a Muslim - we must acknowledge instead the fluidity that these individual characters embodied and employed. This is not to deny the occasion of linguistic marking altogether: Hindu characters in Humayun are manifestly more likely to use Sanskrit-derived vocabulary than their Muslim counterparts (immediately prior to the śer, the princess mentions a sundar sapnā, for instance, rather than a khubsürat khyāb: given the several occurrences of khyāb in the preceding dialogue, such a deviation not only gently reinforces her identity, but more importantly enriches, enlivens and varies the dialogue). Yet Mehboob and his writers also employed minor variations in register to exceptional dramatic effect: when Humayun lies dying, for instance, his former enemy Randhir invokes bhagvān, followed immediately by Babur's dramatic prayer to Allah, followed in turn by the Rajkumari's own prayer to bhagvān once again, as Hindu and Muslim alike offer prayers for the Mughal prince's life. If it is indeed divine intervention that the accompanying shots of lightning signify, this divinity is clearly unmarked as either Hindu or Muslim.

Films such as Humayun, then, exemplify the broad horizons of filmic Hindustani: while language differentiation can on occasion mark religious identities, the characters employ a broad range of vocabulary that, crucially, presents no impediments to mutual intelligibility within the context of the film's dialogues. Most importantly, the clear expectation was surely that, excepting the example of Persian already noted, this same broad register would be intelligible, accessible and indeed attractive, to the film's audience.

Yet let us consider an example in which register really does not function to mark out individuals as distinct, yet that language remains broadly conceived and inclusive. The dialogue of S.U. Sunny's Mela (Fair, 1948), written by Azim Bazidpuri, rarely reaches the lofty heights of rhetoric in which Kashmiri's script revels. As such, Bazidpuri uses a decidedly mixed Hindustani register, and largely eschews higher registers and styles. The village provides the setting for this almost wholly unmarked and undifferentiated speech, in which characters frequently employ words of dramatically different provenance in the context of their conversations. A good example is a scene at the village fair, when the hero Mohan (Dilip Kumar) assures the heroine Manju (Nargis) that she has nothing to worry about (using "takliff") as he has 8 annas - more than enough to allow them both to enjoy themselves. Moments later her friend, Basanti, arrives and inserts herself into their conversation and plans: Mohan assures her that his muttered aside, calling on god for help, was nothing of the sort - instead, he was calling down blessings ("āsirvvād") for her. 
Such uses are unremarkable in the context of the film, however. Distinction, where it is to be found, comes primarily through the songs of the film (discussed in section 2 below), and distinctive speech registers are employed only in scenes that mandate a particular mode of expression - for example, the Persianised legalese of the court room. The paradigm is one of accessibility, and the context is one wherein characters converse in a shared language; this is a language that is the property of no individual nor community, is understood by all, and that easily accommodates Sanskritic or Perso-Arabic terms as and when they seem appropriate. Thus the dialogue of Mela in many ways exemplifies the feasibility of unmarked Hindustani as the language of cinema: the Sanskritic äsirvād and the Arabic-derived taklīf, to use the same example, are neither Hindi not Urdu in their oral presentation and aural reception; this tale of ill-fated romance is concerned with entertainment and pleasure, a good story aiming at popularity rather than any ill-conceived notion of linguistic purity.

One moment of non-Hindustani intervention occurs in Mela when the hero Mohan's rival for Manju's affections attempts to use English in order to impress his fellow villagers as to the validity of his argument. The English is garbled, creating a comic moment for those sufficiently fluent in the language of command to enjoy, and establishing a pattern of comic characterisation that has been successfully employed many times in the history of Hindustani film.

English functions as the marker par excellence of authority, whether correctly employed or otherwise, both here and in Chetan Anand's Neecha Nagar (The Low Village, 1946). In Anand's film, however, English is used in a similar fashion to the heavily Persianised dialogues from Mehboob's Humayun, with the former displacing the latter in this contemporary milieu as the signifier of authority and authoritative discourse. Such a transformation has, I argue, significant implications for the role of filmic Hindustani as a language of inclusivity in a modern setting: if the "other" is marked by English, and as we shall see by class, how much closer does that make the average Indian, whether Hindu or Muslim, to his fellow subalterns? Two episodes in Neecha Nagar deserve somewhat close attention in this regard: an early scene in which the residents of the eponymous low village come to confront the landlord over his plans to redirect a water flow, and its attendant sewage, through the village; and a later scene in which one of the villagers, Sagar, returns to his friends after a private meeting with the landlord.

The group of villagers which goes en masse to the landlord's house is diverse in religion, age and temperament, though indistinguishable from one another when it comes to speech register. It is the hero's friend, Sagar, who makes the first break from their uniform way of

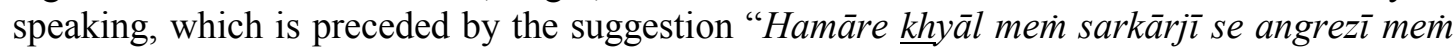
bāt karnā cāhie." ("I think we should speak to the landlord in English.") Accompanying his attempts to smarten his appearance - brushing off his shoes and arranging his trousers - this receives approval from another of the villagers, and the moment marks both orally and visually an aspiration to participate in authoritative discourse. Yet, when they proceed to meet the landlord, the conversation takes place in Hindustani, accented by the Persianised vocabulary of politeness ("taśrîf rakhiye", etc.). It is only in a moment of frustration that Sagar blurts out his garbled, frantically rushed assertion in English that the landlord should not redirect the water towards the village - "What you see what is want don't you see what it mean that the dirty nalā (sewage) should not go there do you see" - an attempt at speaking the language of power that is utterly ignored by the landlord, who turns instead to the khadiwearing leader of the group and the Muslim village elder to continue the discussion in Hindustani.

This brief intervention on the part of English is accompanied by a variety of other oral and visual signifiers of distinction. The landlord is seated, luxuriating in a cigar and, while he passes a box of cigarettes out to the villagers, all of whom take one, the apparatus of smoking, and implicitly of leisure, serves to mark out the difference in class and wealth. In terms of dress, the landlord wears a well-cut western suit and tie, while the villagers are dressed in an assortment of Indian garments, with only the aforementioned Sagar sporting a poor imitation of western fashion. And framing these visual signifiers is the difference in the manner of speaking, rather than the register. The landlord's competence in English is taken for granted; 
the villagers' limited facility is mockingly displayed. Moreover, the landlord speaks in a measured pace, firmly but quietly, and with quite distinct enunciation, while the speech of (most of) the villagers is hurried, loud, and markedly less clear. Linguistic marking, as it occurs here, is done through the manner and mode of delivery, and highlights differences of class, rather than religion. The Muslim village elder's speech is the closest to the landlord's, but this is a mark of dignity rather than religious affiliation.

The second scene for consideration once again involves Sagar who, having received the hospitality of the landlord (and, it should be noted, having tried rather pathetically to reproduce the language of polite discourse, bobbing his head and repeatedly offering a nervous and doubled "śukriyā, śukriy $\bar{a}$ " when presented with tea, a cake, a cigar, another cigar, and sugar) returns to the village to give an account of his meeting. Wearing a suit, and smoking a cigar, Sagar makes his entrance: "Hello, how do you do? Māf kījiegā mujhe zarā der ho gayī, magar maìm sab tay kar àyā hǜm, āp ko'̄̄ fikr na kīji'e - sab kām ban gayā." ("Please forgive me, I'm a little late, but I've come having solved everything - please don't worry, everything has been sorted out.") He assures his assembled friends that the rerouting of the waterway will not cause any problems, and should there be any filth, it will be easily fixed. His friend Balraj, however, immediately intuits what is patently obvious to the film audience: that, beyond his imitation of the landlord in terms of style, clothing, and affectation, he is in fact precisely reproducing the arguments he has just been presented with. The argument is framed in English, and with it the visual signifiers of authority, yet it is unsuccessful. The villagers recognise their other; he is marked by English, marked by class and, in the case of Sagar, marked by class betrayal.

Anand and his screenwriter, K.A. Abbas, created a complex and subtle interlacing of signs that escaped government censorship despite its clear invocation of the Gandhian village utopia and its associated symbols (khadi, handloom, etc.). ${ }^{5}$ Language was used as one signifier among many to mark out the morally lax and, as I have argued, the other. Rather than an opposition between Hindi/Hindu and Urdu/Muslim - the widespread distinction being made at the time - this distinction was being made between English/Anglicised/corrupt on one hand, and Hindustani/authentically-Indian/pure on the other. This latter category was therefore indivisible, constituted as a co-operative and harmonious whole, in which members of both religious communities co-existed and defined themselves against a class-based oppression. The cohesive potential of this shared and implicitly linguistic identity is demonstrated in the film's denouement: addressing the assembled municipal board, covered in mud having washed herself in the filthy water now flowing through the village and causing widespread sickness and even death, our heroine adds to the mixed register of Hindustani employed throughout the film a critical element of the language of command: "Krpa karke is tajvizz par vot le lïji'e." ("Kindly vote on this proposal.") The Sanskritised, Arabicised and Anglicised come together in a microcosmic exemplification of the fluid nature and inclusive capacity of this filmic language, ${ }^{6}$ the vote goes in favour of the villagers, and the landlord suffers a rather extended heart attack and painful death shortly afterwards.

We have seen how register functioned in inclusive, heterogeneous ways in several films of the 1940s - particularly Humayun, Mela, and Neecha Nagar. While the potential existed, and was employed, to mark out religious identities, this was frequently done in the context of a broader conceptualisation of the Hindustani language as inclusive of different religious identities and as realised through the oral media. Of course, there are counterexamples aplenty. S.M. Yusuf's Nek Pervin (Pious Parveen, 1946), for instance, is an example notable for the consistency of register. Its characters speak in such a way that differentiation is almost impossible: of course, the preponderance of Muslim characters might well explain the consistently Persianised Hindustani that is employed. Occasional uses of English speech and phrases ("very good", "it is very bad") serve to mark out slightly comic moments or comic (male) characters; otherwise, characters speak in a remarkably uniform Urdu-Hindustani register regardless of class, gender, age or situation. As I discuss at further length in section 3 below with regard to paratexts, the target audience of this Muslim social was almost certainly a predominantly Muslim one, and Allah is frequently invoked, for favour, in gratitude and the like. Nevertheless, the register is not so Persianised or "Urdu" that it would have been 
incomprehensible to a "Hindi" audience, and there are no oral/aural moments that would alienate or exclude audience members in the thorough manner of the surah peritext analysed below. In a similar but opposite manner, Hindu mythologicals such as Vijay Bhatt's Ram Rajya (Ram's Rule, 1943), in which the register is almost entirely śuddh Hindi, remind us that not all directors or writers chose to utilise the full spectrum of Hindustani in their films. However, it is clear that films in which a more restricted register - that is, a register that could be characterised quite distinctly as Hindi or Urdu and accepting little in the way of compromise - was employed tended to take as their subject matter a theme that was intrinsically suited to such exclusivity. In the absence of a formal, programmatic determination of what should or could constitute the language of film, directors and screenwriters were free to draw on the full range of the Hindi-Urdu spectrum, and did so to dramatic, creative and inclusive effect.

\section{Poet or Lyricist? The Vicissitudes of Genre}

While our discussion of register as it was used in film dialogues has revealed the plurality of approaches to Hindustani that existed, it tells only half the story. Songs - lyrics and music are an incredibly important part of Indian and Hindustani cinema. As Tejaswini Ganti has noted, they often function as advertising for the film itself, released ahead of the film and, thus, already familiar to audiences by the time they see the picture. (Ganti, 2004; 15) Furthermore, other studies have demonstrated the inseparability of the songs from their films, and the necessity of appreciating them as part of an organic whole (Morcom, 2007), rather than dismissing them for failure to conform to some kind of empirical or classical realism (cf. Dwyer, 2000; 107-8). Perhaps most significantly, the poetry of songs represents the most obvious link between the then new, oral film and the literary forms that long predated its arrival.

With this in mind, I turn once again to Sunny's Mela. This tragic romance was one of the early films for which Shakeel Badayuni wrote the lyrics. I suggest that the contrasts between the various moments of song and poetry - inextricably linked with their connecting dialogue and central to the narrative and affective power of the film - provoke fruitful comparisons with the corpus of poetry that Shakeel, as both film lyricist and "serious" poet, has left behind. Seeing these moments as embedded within the broader contours of the filmic text, especially its visual scenes but also the mode of delivery - what I am terming the multiple textures of Hindustani - allows to examine just how poetry and song featured in the film, and how they compare with their other, more "literary" contexts. Such contrasts enable us to appreciate the full extent of the linguistic and symbolic range that the lyricist, in conjunction with the screenwriter, could and did employ in making a Hindustani film.

Shakeel Badayuni (1916-1970) is well known for his film lyrics, particularly those in Mughal-e Azam, Chaudhvin ka Chand, and Sahib, Bibi aur Gulam - three particularly memorable and successful productions on which he worked. A graduate of Aligarh Muslim University, he began working as a lyricist when he moved to Bombay in 1946, leaving his relatively poorly paid government job in Delhi. He was a prolific poet as well as lyricist - his first collection of poetry, Ra 'nāiyāin ('Graces'), was published in 1944, and subsequent collections and later reprints testify to the enduring popularity of his work. ${ }^{7}$ This popularity rests, no doubt to a large extent, on the penetration achieved by his film lyrics - many have entered the popular consciousness of Hindi India and remain there to this day.

Turning to the film itself, however, it is interesting to note the variations that exist between various parts of Shakeel's contributions. The most striking difference is, in fact, in the songs: Shakeel proved his own versatility and adaptability, with Hindustani songs such as 'Yeh zindagī ke mele' included alongside other, more celebratory songs such as 'Āe sāvan rut āȳ̄', the latter clearly taking its thematic and linguistic inspiration from the pre-modern Braj lyrics of Krishna devotionalism. (This was a pattern Shakeel followed in other, later films; consider, for instance, 'Pyār kīyā to ḍarnā kyā' and 'Mohe panghat pe' from Mughal-e Azam.) Yet these distinctions are further enhanced, along with our appreciation of Shakeel's own range of expression and poetic diction, when these lyrics are set alongside snippets of their author's 
more formal poetry, as they are in Mela. ${ }^{8}$ These various selections - surrounded by the dialogue of the characters (written by Azim Bazidpuri), and encased in the overarching narrative continuum of the film - can of course be juxtaposed and contrasted on the basis of their linguistic diversity alone. However, I turn to the idea of texture as a way of more fully appreciating the role these various utterances play in the film, and as a means by which the film as a single speech act can be understood as constituting a distinct intervention in the linguistic milieu of Hindi-Urdu. In doing so, we can begin to appreciate how register functions not as a proof of irreconcilable difference or distinctiveness, but instead is exploited, appreciated and enjoyed as an element of deep, filmic texture.

I use the term 'textures' to refer to the ways in which language is situated in a broader, meta-linguistic, and here particularly visual context. This denotes a mode of perception - of looking, of reading, of appreciating and here particularly of listening - that implicitly assumes the involvement of multiple senses, for it recognises the inseparability of the linguistic utterance (speech, song, text) from its attendant extra-linguistic accoutrements (speaker, audience, script/page). We are able, of course, to examine the linguistic elements of any given texture in isolation, but in doing so we risk denuding these speech acts of their markers, and blinding ourselves to the full expressive richness of any given utterance. Indeed, I believe such an investigation of texture may provide a way to reconcile the "visual bias" (Morcom, 2007) that has predominated in particularly western film scholarship with the self-evident importance of the song to the Indian cinema, and suggest albeit only in the most tentative way a mode of reading simultaneously the lyrical, musical, and visual.

It is with this in mind that we can turn to the poetic intervention mentioned above. We have already heard the film's signature song:

\section{Ye zindagī ke mele duniyā meì kam na honge}

Afsos ham na honge...

Itself penned by Shakeel, the song is sung against the backdrop of the village fair. It is entirely worldly, in terms of both content and presentation. Hardly upbeat, the song considers the transitory nature of human existence, expressing regret that, whatever goes on, we cannot remain to see it all ("There will be no shortage of fairs [read: spectacles] in this life: unfortunately, we won't be here [to see them]"). However, we then cut to something that, in tone, imagery, delivery and context, is something recognisably different: an Urdu śer:

Vahī zindagī vahī marhalle vahī kārvān vahī rāste,

Magar apne apne maqām par kabhī tum nahìm kabhī ham nahìm.

That same life, those same stopping points, caravans and roads,

But we were never in our own place, neither you nor I.

The śer is taken from a longer ghazal by Badayuni ('Merī zindagī pe na muskarā mujhe') that, considered as a whole, on the written, published page, provides a further point of comparison with the filmic utterances. ${ }^{9}$ Most striking, however, is the thematic continuity between the couplet and the preceding song. Both reflect on missed opportunities, with the resting places, roads and journeys of the śer mapping out life's journey in a decidedly more sombre tone (there are no "fairs" in this version). Yet this thematic continuity serves to highlight the disjuncture between the two moments: their styles and contexts - their textures are wholly different. The former is sung by an anonymous narrator and, despite its somewhat melancholic outlook, is accompanied by a rather sprightly tune and, as already mentioned, overlayed with images of fun and enjoyment at a fair. This oral and visual backdrop alleviates the melancholia, suggesting rather than explicitly articulating a sentiment akin to carpe diem; if life is indeed transitory, one should enjoy its more pleasant moments (see Figure 1). ${ }^{10}$ The texture of the s'er, on the other hand, is emphatically different: the landscape shifts abruptly to an eerie, desolate vista, through which our hero Mohan, nearing the end of his life, wanders alone through the dark. The couplet is delivered in portentous tones, declamatory and yet sombre. The formal nature of this distinctively Urdu couplet is thus further marked apart by 
its filmic texture. Essentially, the texture and in particular the mode of delivery serves to mark this poetry as poetry, as a genre apart from what has come before.

\section{Figure 1 Mela screenshots: "Ye zindagī ke mele" and "Vahī zindagì"}

The linguistic register of the ser is not dramatically different from that of the song that preceded it; its difference is marked out more by its texture than any particularities of register. The couplet is in fact the least Persianised of the six couplets that make up Badayuni's published ghazal, which in other verses abounds with distinctive markers of Persian syntax (especially the free use of the izäfat) and Arabic-derived vocabulary. ${ }^{11}$ What this demonstrates, however, is the capacity of film to include elements of formal, "high" literature, in an admittedly somewhat limited context, alongside the more demotic film song, and to move swiftly and dynamically between moods, registers and textures. The distinction between poet and lyricist may well then be less than imagined by later critics and literary historians such as Muhammad Sadiq, who freely denounced poets for "selling out" to the film industry - spending their time composing popular, pleasing, and implicitly inferior verses and dismissed their work out of hand. ${ }^{12}$ Certainly, Badayuni's work testifies to the high standards he achieved in both arenas, with his accomplished song lyrics and elegant poetry here at least co-existing side by side.

A later song serves to demonstrate not only Badayuni's own range, linguistic competence and versatility, but also the accommodating nature of the filmic medium regarding divergent registers, forms and traditions. The decidedly upbeat 'Āe sāvan rut āy $\overline{1}$ ' posits the Mohan of the song ("Mohan ghar $\bar{a} j \bar{a}$ "/"Mohan come home"), as both an epithet of Krishna and the Mohan of the film. Manju takes the place of Radha or the principle gop $\bar{\imath}$, while her female companions join in the recitation of the chorus. Mohan's own intervention, "Duniya hai do din kā melā kuch ro le kuch ga le" ("The world is a two-day festival: cry a little, sing a little"), both echoes the theme of the film and 'Ye zindagi ke mele' in its call to seize the day and make the most of the transitory passage of life and love, and also evokes the carefree abandon with which Krishna conducts his līla in so many devotional Braj lyrics. The setting is idyllic, with the women happily gathering wheat and singing while they work their sickles. The song contrasts distinctively with the register, tone, and literary heritage of both 'Ye zindagì' and 'Vahī zindagì', yet all these poetic moments are linked together by the common context of the neutral, unmarked and accommodating register that Bazidpuri employed for the film's dialogue.

Even this one example of Sunny's Mela shows how films had the potential for an expressive breadth that surpassed even the most eclectic of literary journals. Poets such as Shakeel employed varied and divergent registers, invoked a range of literary motifs and heritages, and in doing so demonstrated the expressive potential of a broadly conceptualised Hindustani that stretched from the formal and established tones of classical Urdu poetry to the rich and evocative phrases and phonetics of Braj Bhasha devotionals. ${ }^{13}$ Significantly, these examples show Badayuni's deliberate creation of quite different poetic compositions - he wrote the song lyrics as song lyrics, and published his poetry as poetry, lent only an appropriate couplet to the film script rather than the entire ghazal and thereby kept these two strands of production somewhat separate. ${ }^{14}$ Most conclusively, we can apprehend the centrality of song and music, and of poetry, to an understanding of the language of film in the broadest sense. As poetry entered into film, either imported in its original state or through the expressive medium of song, it became less the "core marker of linguistic difference" (Lelyveld, 1993; 210), and more a source of pleasure that took full advantage of the liberating effects of orality and aural reception, enabling the consumption of Hindustani in an environment that was beyond the scope of literary or linguistic puritanism.

\section{Free from Script? The Filmic Paratext}

Insofar as a film, much like any other linguistic product, may be analysed as a 'text', it seems pertinent to consider the ways in which Hindi-Urdu films of the pre-Independence period 
were framed and mediated by their paratextual elements. In one sense, films represented perhaps the greatest potential for the articulation and employment of a broadly conceived Hindustani, as the oral nature of the medium apparently removed the thorny and persistently intractable issue of script from the equation. ${ }^{15}$ Indeed, David Lelyveld's comparison of the development of very different language registers in the broadly concomitant media of radio and film attributes the evolution of the starkly divergent styles of Hindi and Urdu on All India Radio, as opposed to the mixed and relaxed nature of "Filmi Hindi", to both the requirement that radio programmes be prepared in written form prior to broadcast, and the intense government and literary scrutiny that radio language received (scrutiny from which film remained largely free during the period in question) (Lelyveld, 2002). However, while the orality (and, let us not forget, visuality) of these filmic texts may be their distinguishing feature, they were in fact (or, perhaps, of course) framed by paratextual elements that were, inescapably, written.

Embracing the hermeneutic continuum of film-text-opus so clearly articulated by Georg Stanitzek (Stanitzek, 2002), we are free to investigate the Hindi-Urdu filmic forms of what Gérard Genette has identified as paratext, and has suggestively defined as "a zone not only of transition but also of transaction: a privileged place of pragmatics and a strategy, of an influence on the public" (Genette, 1997, 2). Indeed, and as we shall see, it is precisely the discontinuity between the oral nature of the film and the written nature of its paratextual elements that makes this investigation, in the context of the Hindi-Urdu controversy, so potentially illuminating. Script, and on occasion multiple scripts, figured in the audience's reception of any given film, both during and immediately before and after the consumption of the film itself (what, in Genette's terminology, would constitute the peritext), and in the larger public sphere through advertising, review and commentary (our extrapolation of Genette's epitext). These peritextual elements - titles, credits, and other miscellaneous script moments inserted in and around the film - are linked to certain epitextual elements, especially advertisements, by the common agency of production that they share. They constitute a frame for the film proper that is constructed and disseminated by the producers (in the broadest sense) of the film and, as I shall argue, provide us with certain indications of the attempts by film producers and exhibitors to anticipate, and to some extent construct and shape, their audiences. While such factors can serve as an indicator of expected appeal, other epitextual elements - chiefly commentary and reviews - can serve as a measure, albeit a limited one, of consumption and reception, further elaborating our understanding of the complex linguistic structures that surrounded this linguistically fluid, if not ambiguous, medium. Taken as a whole, we will see how the language of film in general, or of a given individual film in particular, was determined, deployed, represented and received in a variety of quite different, and sometimes quite surprising, ways.

\subsection{An Islamic Peritext}

A dramatic example of peritextual intervention comes at the end of Yusuf's Nek Pervin. The happy resolution of the story, in which the protagonist is rewarded for her patience and unwavering faith in God with the ultimate reform of her husband, is followed by the appearance of the Quranic, Arabic surah quotation "Inna Allāha ma 'a al-șabirīn", above its Urdu translation "Khudā șabr karne vālon kesäth hai" ("Allah is with those who are patient"), projected onto a moving background of clouds. The visual impact of this conclusive, and profoundly moralistic, coda is heightened by the use of the distinctive Thuluth script for the surah and Nastaliq for the Urdu translation. Even more striking is the contrast between this decidedly Islamic script visual, and the inherently less marked, more mixed, and predominantly Roman nature of the film's other peritextual elements. As is clear in Figure 2, Roman script is the default choice for the name of the studio (along with its Latin motto, Surgite Lumen Adest, "Arise, the light is near"), is chosen to signal The End, and is the most prominent and central of the three scripts used for the film's title, perched between the Nastaliq and Nagari versions (it is also used for the credits). 
Perhaps such peritextual anomalies are simply another marker of the 'Muslim social', delineating it from the other genres and sub-genres of Hindi-Urdu film. Compare, for instance, the peritexts that framed two other contemporary productions: Anand's Neecha Nagar and Mehboob's Humayun (see Figures 3 and 4). Perhaps influenced in some way by winning (or by entering) the Cannes film festival of 1946, Neecha Nagar is framed entirely by Roman script, and indeed by significant passages in English, and eschews altogether the use of either Nagari or Nastaliq in titling. Mehboob's Humayun, on the other hand, demonstrates a similar preponderance of Roman and English in its textual frame, but includes the already common feature of dual titles in both Nagari and Nastaliq. However, its Mughal/Islamicate theme has not resulted in an increase in Urdu/Nastaliq, and certainly nothing comparable to the surah quotation in Nek Pervin.

\section{FIGURE 3}

\section{FIGURE 4}

Such comments on the peritext of the film are in no way intended to suggest that the Quranic quotation was in any way inappropriate or out of context; rather, it is clear that the narrative of the film builds seamlessly to this parable-like denouement. Nevertheless, following Genette's schema, it is useful to consider what mediating effects such a distinctive textual coda may have had on contemporary audiences. We can appreciate the enabling effect that such Muslim socials must have had on Muslim audiences, whereby the moral and moralising nature of the subject matter ameliorated anxieties over the presence of particularly female family members in such desegregating public spaces as the cinema hall (indeed, the opening scene of the film, in which a moralising play directed and stage-managed by the character of Parveen is presented in the context of a girls' school, can be read as a somewhat selfreflexive, generic commentary on the positive potential of this relatively new form of entertainment). ${ }^{16}$ In such cases, a verse from the Qur'an would have been an affirmation not only of the film's plot, but also of the expectations generated by the title alone (Nek Parvin, or Pious Parveen, indicates the direction of the story just as clearly as the title of Nazir Ahmad's well-known and thematically similar 1869 novel, Mirāt ul- 'Arus, or The Bride's Mirror (Ahmad, 2001)). The title would have functioned in a similar way for non-Muslim potential audience members: there is almost nothing else a film with this title could be about, and it is hard to imagine viewers arriving in anticipation of anything other than a moral, Muslim tale. This said, the exclusively Perso-Arabic form of this penultimate textual intervention, lacking an oral rendition (the Urdu translation of the Arabic would have been, after all, easily understood by speakers of almost any variant of Hindustani), would have been undeniably alienating for those not literate in Urdu. ${ }^{17}$ Without access to contemporary reviews or reactions, it is impossible to assess fully the effect this may have had. However, it is worth remembering that this brief Arabic and Urdu peritext was just that: brief, and in a wider context of Roman script and inclusive titling, both in Nek Pervin and other films from the period (the same was true of, for instance, Mela, with the prominence of the Roman title greatly exceeding that of the Nagari and Nastaliq - see Figure 5). ${ }^{18}$ As such, it seems appropriate to view this as a potentially alienating element, which was recognised as such and therefore introduced only sparingly, thereby allowing a film such as Nek Pervin to cater to a primary, perhaps intended or imagined audience of Muslim viewers (creating, in Genette's terms, a small but significant "privileged place"), while not going too far towards alienating potential (paying!) customers with less or no familiarity with Arabic. The dominant trend, indicated by the plurality of peritextual instances, seems to have been towards the neutral ground of Roman script, with a sprinkling of Nagari and Nastaliq thrown in for good measure. 
Of course, some films were framed by peritexts that were almost entirely in Nagari. Bhatt's epic mythological Ram Rajya is a perfect example of this. While the title itself displayed the common, three-script formula discussed above, the most prominent script was Nagari, and while the studio name was presented in Roman, other elements - including the dedication, the cast and crew credits, the closing screen ("samāpt"), and the striking visual representation of an undivided (British) India framed in petals - were presented exclusively in Nagari/Hindi (see Figure 6). The Hindu theme of this film no doubt justified, if not suggested, such a preponderance of Nagari in its framing. Returning again to Genette's formulation, such a framing suggests the creation of a privileged space of interaction and inclusion, though to a decidedly less exclusive extent than that created by the surah in Nek Pervin. However, as we shall see below in regard to advertising, the textual framing of even this most emphatically Hindu subject matter was considerably more varied than its peritexts might suggest.

\section{FIGURE 6}

\subsection{The Film Marketplace: Advertising Across Scripts}

If the examples of peritexts examined above constituted the primary means by which a filmic text was framed by its producers, the epitexts produced as advertisements for films were another strategy through which producers created an interface between the film and its (potential) audience. Moreover, advertisements were per force affected, though not necessarily restricted, by the intended institutional spaces in which they were placed. The Delhi-based Urdu literary journal Adīb (or, as it styled itself in English/Roman, The Adeeb) provides an excellent lens through which to examine the dynamics of film advertisements' interaction with print media, due to the wide variety of film adverts that it carried. ${ }^{19}$ The languages, scripts and styles employed by advertisers not only reveal more about the marketing strategies they used, but also provide a window into the readership of the journal a print audience reimagined as a film audience.

Adeeb classified itself, perhaps somewhat self-consciously, as "a purely literary monthly Magazine of high standing". That this description began to appear in the journal on a regular basis some months after it began running adverts for films, and printing a semi-regular column on Film $\bar{\imath}$ Khabaren (Film News), in November 1941 suggests both that film adverts represented a significant source of revenue, and also that they were being proactively marketed to an audience that was self-consciously literary. That such an audience was interested in consuming films does not directly contradict Lelyveld's assertion that it was the language of radio that was of greatest concern to the literati, but it does serve as an important reminder that films were not targeted at an exclusively 'low-brow' audience (Lelyveld, 2002). Furthermore, in addition to the broad coverage of historical and contemporary literature and augmenting the somewhat unvarying lithographed Urdu, relatively high resolution film stills appeared regularly on the inside front, and sometimes back, covers of Adeeb. From the outset then, the relationship between the apparently divergent worlds of films and literary journals could be a mutually beneficial one: film producers gained a vehicle for publicity; an attendant commentary began to appear in close proximity to the adverts (in the case of Adeeb, this was almost always at the very back of the journal); and an otherwise visually quite drab publication could allow some of the glamour of film to rub off on its pages.

The majority of film advertisements in this Urdu journal were, like that for Shaukat Hussain Rizvi's Khandaan (1942) in Figure 7, solely textual in nature, and entirely in Nastaliq. However, this was far from the only format. Other adverts varied greatly in terms of their complexity and visual impact, including variously: extremely detailed (if not verbose) descriptions of the plot (as in the case of an advert for Sohrab Modi's 1941 film Sikandar); lithographed, stylised images of the characters (see the advert for Vijay Bhatt's 1943 film Ram Rajya in Figure 10); and recognisable, relatively high definition photographs of the stars (see Figures 8 and 9). This plurality of Urdu-language adverts in an Urdu journal is, of course, unremarkable. Moreover, the variation in the composition of the adverts as regards 
images corresponds with a similar variation among adverts for other products in the same journal's pages, and in a similar proportion (though it seems only film adverts went so far as to include photographic images, stylised images were abundant). However, the inclusion of images of whatever format was only one method through which their producers heightened the adverts' visual impact. An alternative approach, which appeared regularly in the pages of Adeeb, was the use of other scripts, and there are several examples in which Nastaliq text was supplemented by, or in some instances almost entirely substituted with, Nagari and/or Roman text. Once again, text intruded into this predominantly oral media (film) through the films' paratextual elements, and thereby reintroduced the potential for exclusion based on script that films, as oral media, were at least theoretically supposed to be able to transcend.

The criteria for the use of Nagari are not, however, immediately discernible. The advert for P.Y. Altekar's 1943 film Mahatma Vidur (see Figure 11) indicates one possible situation; the mythological story of Vidur, half-brother of Dhritarashtra and Pandu in the Mahābhärata, perhaps called for an element of Nagari as a denominator of Hindu identity to be introduced into the composition. In such an analysis, the brief instance of Nagari/Hindi in an otherwise and overwhelmingly Nastaliq/Urdu advert is no more intrusive or alienating than the exceptionally brief albeit indicative peritextual Arabic featured in Nek Pervin, though it retains a symbolic and communal significance, creating for the Nagari reader a limited privileged space and perhaps drawing the eye of the Hindu reader to the script of his scripture on which the film was based. However, other counterexamples indicate that the use of Nagari in adverts placed in an Urdu journal did not correspond to such a clear-cut (and possibly overdetermined) schema. Consider, for instance, the advert for Bhatt's Ram Rajya (see figure 4.10): this big budget and popular Rāmāyana-based mythological, with its national allegorical elements, would have been an obvious contender for a Nagari/Hindi title in the above formulation, yet the only addition to the Nastaliq/Urdu advert comes in Roman script. Other adverts for Hindu devotional or mythological films - Chaturbhuj Doshi's Bhagat Surdas/Bhakta Surdas (1942) or V. Shantaram's long-running and hugely successful Shakuntala (1943) - appeared devoid not only of Nagari, but also of images (though, it should be noted, both ran as full-page adverts similar to that for Ram Rajya). Clearly then, Hindu subject matter did not mandate the use of Nagari in any consistent fashion in an Urdu publication context. This Hindu subject matter had to be written down in Urdu for this publication, though the occasional inclusion of Nagari in adverts that were obviously specifically formulated for an Urdu-language/Nastaliq-script publication remains significant. Further counter-examples come in the form of adverts such as that for Kisise Na Kehna (1942): here, while Nastaliq certainly predominates, it is mingled with both Nagari and Roman scripts, producing an effect similar in some ways to the standard multi-script title peritexts discussed above. However, two elements mark this epitext apart from such titles. Firstly, the real majority of the information regarding the film is imparted through Nastaliq and Urdu; the only elements that are not available through this script are rather banal elements, including the somewhat mystifying "They salute the show world!". Secondly, the Nagari rendering of the film's name borders on the illiterate: the correct, and correct in Nastaliq, "kisī se na kahnä" has been corrupted to the bizarre or perhaps simply careless kissise na kahenā. Perhaps indicative of faulty transmission via Roman, of unfamiliarity with Nagari on the part of the producers of the advert, or of simple carelessness, this certainly suggests that the inclusion of Nagari in such a context was, at the most, of secondary importance. Finally, its use in a romantic, rather than mythological, context demonstrates the almost random way in which Nagari could, did or did not feature in film adverts in this otherwise Urdu journal.

Of course, the very existence of these adverts for Hindu-themed films in the pages of an Urdu journal, and alongside communally non-specific genres such as romance, not only testifies to the communally-neutral or at least inclusive aspects of Adeeb as an Urdu literary publication, but also suggests an inclusive and broad marketing strategy on the part of film producers and exhibitors. ${ }^{20}$ Whether these adverts were placed by distributors or exhibitors, however, the fact remains that an Urdu journal was considered a reasonable space in which to advertise Hindu-themed mythologicals. Nevertheless, print advertising necessitated the use of 
script: at this point of interface with the consuming public, the limits of filmic orality become starkly apparent. Such limits run counter to the abstracting, or depersonalising, aspects of textuality that Jack Goody identified as critical to the very function of writing, and whose formulation scholars of advertising have since effectively employed at least in monolingual contexts (Goody, 1977, 44; Schudson, 1984). The process of tying an utterance not so much to the written form in the abstract, but to a specific script or set of signs in the specific, necessarily restricted the potential audience in this multi-lingual context, and framed the oral film in concrete, textual terms. ${ }^{21}$

We are left with a somewhat haphazard, or perhaps merely relaxed, approach to the use of script in the paratextual elements associated with films. We can point to the multiplicity, even in our relatively small sampling, of linguistic and script-based strategies which demonstrate the lack of anything approaching a positive correlation between the subject matter of a film and the language or script in which it was framed. The prevalent defaults - to Roman script in film titles and credits, and to the language and script of the publication in which adverts ran suggest, if not a determined effort to avoid the issue of Nagari versus Nastaliq, at least a recognition of the potentially alienating effect that either script may have had. Exceptions to this rule serve to prove it, and Genette reminds us of the inevitable specificities and subtleties that inhere to the "effects that result from the composition around a text of the whole of its paratext", and the possibilities of individual analyses (Genette, 1997; 10). So, while this discussion focuses on the broad sweep of interactions between script, language and genre, it remains sensible of the ways in which, in individual cases, paratextual elements could function as markers of difference. Whether as a flash of Arabic at the close of Nek Pervin, or the significant visual of Nagari in an Urdu-script advert for Mahatma Vidur, these paratexts certainly acted to differentiate their associated filmic texts from other, emphatically neutral productions. However, in this most commercial of media, such instances of differentiation appear to have been occasional, rather than the norm. Added bonuses for those with access, or small privileged spaces of interaction created for a particular segment of the audience, these limited moments worked to draw that segment closer to the product, without alienating the wider film-going consumer base.

\section{Some Conclusions}

The Hindi-Urdu debate - central to the communal confrontations that had intensified consistently throughout the late colonial period - was hardly new. Questions of language were, however, now and for the first time being worked out in a novel media setting: that of talking films. The new arenas devoted to the articulation of discussion and dissent provided by the 1935 Government of India act, and the opening up of a field of public debate, were mirrored by the almost simultaneous development of a vast and substantively different extension to the parameters of the field of cultural production (see Chowdhry, 2000). This extension was both quantitatively and qualitatively different from the institutional and established realm of formal literary-cultural production: broad in scale and popularity; oral in nature, and aurally and visually consumed; and, fundamentally, more informal and unregulated by elite cultural bodies and organisations. As such, the films of this period require special attention as we seek to understand the evolution of the language of Hindustani film.

This oral extension was, as we have seen, inextricably linked to the pre-existing textual aspects of the public sphere through advertising and other forms of publicity. The orality of films was not - and indeed is not - complete and all-encompassing. The intersections between films and their printed paratexts reveal much about the attitudes of producers, marketers and, by induction and to a certain degree, consumers. Moreover, the diversity or heterogeneity of practices that we have seen in even this brief study demonstrates the fluidity of expectations that existed among members of the aforementioned groups, regarding the language and particularly script of presentation and consumption as manifested on the printed page or in film credits. The trends towards inclusivity and accessibility are undoubtedly 
indicative of the inescapably commercial nature of the filmmaking enterprise and, as I have suggested, exceptions to the rule serve to prove it.

I addressed the issue of the Bombay film industry's nomenclature at the outset of this article, and remain convinced that, from a linguistic perspective at least, the term "Hindi film" remains somewhat unhelpful as an identifier; moreover, I believe that Hindustani film is profoundly more appropriate, especially for the period under consideration. However, I do not intend to become overly concerned with issues that, perhaps rightly, could be dismissed as mere semantics. With regard to the language spoken, and sung, in the films themselves, we have seen how the oral nature of the medium enabled what I have described as the crystallisation of Hindustani - perhaps even the codification of a broader cultural heterogeneity - as the medium of communication. This was an industry at a remove from the cultural and institutional politics that permeated the question of Hindi-Urdu in the heartland of the United Provinces. As such, and free from both institutional interference and indeed from the serious interest of much of the literary and cultural elite, Hindustani was allowed to quite naturally occupy the linguistic space opened up by the advent of sound in film. This was by no means a foreordained process, and we have seen the significant exceptions: homogeneous registers of differentiation that exclude and mark various linguistic (and implicitly religious) identities. Nevertheless, we have seen the inclusive potential of orality, and how various directors, scriptwriters and lyricists ranged across the full expanse of the Hindi-Urdu-Hindustani spectrum in search of the optimum register and mode of expression. We have seen indications of a general inclusivity regarding words of both Sanskrit and Persian or Arabic derivation in the context of film dialogues, the peculiarity of the use of particularly "high" language moments within the oral/aural medium, and the interplay of linguistic and poetic utterances with aesthetic elements within the aural/visual texture of the films; all of which serve to complicate both the communal and linguistic binaries of the Hindi-Urdu debate, and the linguistic classification of the films themselves. The thematics of certain films suggest that this inclusivity may well have been a very deliberate strategy: the inclusive, harmonious past envisioned in Mehboob's Humayun, for instance, would hardly have been suited to a sharp demarcation of religious identities through differences in language or register, and the class-based struggles that formed the heart of Anand's Neecha Nagar was its own brand of contemporary idealism, in which religious differences counted as naught against the differences in power, wealth and social position, that admitted no distinction between variants of Hindustani. Less conscious, perhaps, was the seemingly organic inclusivity of films such as Sunny's Mela, in which the full semantic range of Hindi-Urdu and its associated historical literary traditions were effortlessly integrated into a cohesive, inclusive and entertaining whole. In essence, Hindustani film came to include and contain all the various registers of Hindi-Urdu, at a time when the dominant public discourse emanating from literary and political institutions and elites was focussed on choosing between them.

Quite some scholarly attention has been paid to the various "cultural imaginaries" embodied in Indian cinema: most often the national (e.g. Srivastava, 2007; Kaviraj, 1998) and, in a notable extension, the religious or "secular" (Dwyer, 2006). What I have tried to show is that, within the Hindustani film context and alongside such conceptual imaginaries, language itself played a key and indeed intrinsic role. The key characteristic of this filmic common ground is its diversity. The film world had space for a variety of approaches to language and, while it did not entirely escape the attention of critical commentators, the language of film was allowed to develop largely unencumbered by the debates that wracked the literary world of particularly north India and of All India Radio. The "eloquent language of gesture" was now being accompanied by spoken language at a time of intense demarcation and debate: however, it was undoubtedly the relative freedom of that same language from visual signifiers of language that enabled this eloquent, expansive Hindustani to crystallise on the screen.

\section{Acknowledgements}

I would like to thank Francesca Orsini for her support, enthusiasm, careful criticism and helpful guidance. Sincere thanks also to Rachel Dwyer for her suggestions, comments, and 
many discussions on this and other topics, to Preetha Mani who read an early version of this and saved it from several pitfalls, and to the members of various audiences who heard earlier versions of this and related work. The anonymous reviewer for Bioscope also offered several helpful suggestions, for which I am grateful. This article draws on $\mathrm{PhD}$ research conducted at SOAS, University of London, which was funded by the Arts and Humanities Research Council, UK.

\section{References}

Ahmad, Nazir. (2001) [1903] The bride's mirror. Tr. G.E. Ward. New Delhi: Permanent Black.

Altekar, P.Y. (1943) Mahatma Vidur [Motion Picture]. India: Marathi/Hindi.

Alvi, Abrar. (1962) Sahib, Bibi aur Gulam [Motion Picture]. India: Hindi-Urdu.

Anand, Chetan. (1946) Neecha Nagar [Motion Picture]. India: Hindi.

Asif, K.K. (1960). Mughal-e Azam [Motion Picture]. India: Urdu.

Aziz, Ashraf. (2003) Light of the universe: Essays on Hindustani film music. New Delhi: Three Essays.

Badayuni, Shakeel. (n.d.) Kulliyāt-e Shakīl. Lahore: Makhtabah-e Urdu Adab.

Bhatt, Vijay. (1943) Ram Rajya [Motion Picture]. India: Hindi/Marathi.

Chowdhry, Prem. (2000) Colonial India and the making of empire cinema: Image, ideology and identity. Manchester: Manchester University Press.

Doshi, Chaturbhuj. (1942) Bhagat Surdas/Bhakta Surdas [Motion Picture]. India: Hindi.

Dwyer, Rachel. (2000) All you want is money, all you need is love: Sex and romance in modern India. London: Cassell.

. (2006) Filming the gods: Religion and Indian cinema. Abingdon: Routledge.

. (2011) The case of the missing mahatma: Gandhi and Hindi cinema. Public Culture 23:2, pp. 349-76.

Freitag, Sandra B. (2001) Visions of the Nation: Theorizing the Nexus between Creation, Consumption, and Participation in the Public Sphere. In Rachel Dwyer and Christopher Pinney eds. Pleasure and the nation: The history, politics and consumption of public culture in India (pp. 35-75). Oxford: OUP.

Ganti, Tejaswini. (2004) Bollywood: A guidebook to popular Hindi cinema. Abingdon: Routledge.

Genette, Gérard. (1997) [1987] Paratexts: Thresholds of interpretation tr. Jane E. Lewin. Cambridge: CUP.

George, Joppan. (2011) The many passages of sound: Indian talkies in the 1930s. Bioscope: South Asian Screen Studies 2011:2, pp.83-98.

Goody, Jack. (1977) The domestication of the savage mind. Cambridge: CUP.

Gopal, Krishna and Keshavrao Date. (1942) Kisise Na Kehna [Motion Picture]. India: Hindi

Gopal, Priyamvada. (2005) Literary radicalism in India: Gender, nation and the transition to independence. Abingdon: Routledge.

Hines, Naseem. (2007) From ghazal to film music: The case of Mirza Ghalib. In Heidi Pauwels ed. Indian literature and popular cinema: Recasting classics. (pp. 147-69). Abingdon: Routledge.

Irani, Ardeshir. (1931) Alam Ara [Motion Picture]. India: Hindi-Urdu.

Kaviraj, Sudipta. (1998) The culture of representative democracy. In Partha Chatterjee ed. Wages of freedom: Fifty years of the Indian nation-state. Delhi: OUP.

Kesavan, Mukul. (1994) Urdu, Awadh and the tawaif: the Islamicate roots of Hindi cinema. In Zoya Hasan ed. Forging identities: gender, communities and the state. (pp. 244-257). New Delhi: Kali for Women.

Khan, Mehboob. (1945) Humayun [Motion Picture]. India: Hindi-Urdu.

Lelyveld, David. (1993) 'The Fate of Hindustani: Colonial Knowledge and the Project of a National Language'. In Carol A. Breckenridge and Peter van der Veer eds. Orientalism and the postcolonial predicament (pp. 189-214). Philadelphia: University of Pennsylvania Press. 
(2002) Talking the national language: Hindi/Urdu/Hindustani in Indian broadcasting and cinema. In Sujata Patel, ed. Thinking social science in India: Essays in honor of Alice Thorner. (pp.355-66). New Delhi: Sage.

Ludhianvi, Sahir. (1974) Gātā jā'e banjārāa. Delhi: Punjabi Pustak Bhandar.

Mehra, S. (1931) Hindi Language in Indian Films. Filmland (12 December 1931). Reprinted in Samik Bandyopadhyay ed. Indian cinema: Contemporary perceptions from the thirties. (pp. 71-2). Jamshedpur: Celluloid Chapter, 1993.

Modi, Sohrab. (1941) Sikandar [Motion Picture]. India: Urdu.

Morcom, Anna. (2007) Hindi film songs and the cinema. Aldershot: Ashgate.

Mukhopadhyay, Urvi. (2013) The 'medieval' in film: Representing a contested time on Indian screen (1920s-1960s). New Delhi: Orient Blackswan.

Pauwels, Heidi. (2007) Bhakti songs recast: Gulzar's Meera movie. In Heidi Pauwels ed. Indian literature and popular cinema: Recasting classics. (pp. 99-120). Abingdon: Routledge.

Rajadhyaksha, Ashish and Willemen, Paul. (1999) Encyclopaedia of Indian cinema: New revised edition. London: Fitzroy Dearborn.

Rizvi, Shaukat Hussain. (1942) Khandaan [Motion Picture]. India: Hindi.

Roome, J.C. (1931) Future of the talkies in India: Interview with Sheikh Iftekhar Rasool on the prospects of establishing sound studios. Filmland (4 July 1931). Reprinted in Samik Bandyopadhyay ed. (1993) Indian cinema: Contemporary perceptions from the thirties. (pp. 126-8). Jamshedpur: Celluloid Chapter.

Sadiq, Mohammed. (1960) Chaudhvin ka Chand [Motion Picture]. India: Hindi-Urdu

Sadiq, Muhammad. (1984) [1964] A history of Urdu literature. Delhi: OUP.

Schudson, Michael. (1984) Advertising as capitalist realism. In Schudson, Advertising, the uneasy persuasion: Its dubious impact on American society. (pp. 209-33). New York: Basic Books.

Shantaram, V. (1943) Shakuntala [Motion Picture]. India: Hindi.

Srivastava, Sanjay. (2007) Passionate modernity: Sexuality, class, and consumption in India. Abingdon: Routledge.

Stanitzek, Georg. (2005) Texts and Paratexts in Media. Tr. Ellen Klein, Critical Inquiry 32 (Autumn 2005) 27-42.

Sunny, S.U. (1948) Mela [Motion Picture]. India: Hindi.

Trivedi, Harish. (2006) All kinds of Hindi: The evolving language of Hindi cinema. In Vinay Lal and Ashis Nandy eds. Fingerprinting popular culture: The mythic and the iconic in Indian cinema. (pp.51-86). New Delhi: Oxford University Press.

'Ugra', Pandey Bechan Sharma. (1924) Pālaț, in Matvālā (19 July 1924); Ruth Vanita tr. Kept Boy. In Ugra/Vanita (2006) Chocolate and other writings on male-male desire. New Delhi: OUP.

Vasudevan, Ravi. (2010) The melodramatic public: Film form and spectatorship in Indian cinema. Ranikhet: Permanent Black.

Yusuf, S.M. (1946) Nek Pervin [Motion Picture]. India: Hindi-Urdu

\section{Notes}

\footnotetext{
${ }^{1}$ Studies of Indian cinemas invariably run up against the issue of nomenclature, whether knowingly or otherwise, and particularly in this 'Hindi' context. How should we refer to the product at hand, delineating its specificity, its linguistic and/or regional boundaries, while avoiding at times unhelpful linguistic labels? This article examines the Hindi-Urdu-Hindustani cinema of 1940s India. Produced in Bombay, and marketed strongly in the north (including, perhaps most prominently, the Punjab, which was the biggest market for films generally: see Chowdhury, 2000; 17), these films cannot be simply classified as Bombay films, given the concomitant and not infrequently overlapping production of Marathi language films in the same city and oft-times studios. They certainly cannot be classed as "Bollywood" productions (Vasudevan, 2010; 304 and, for a fuller discussion of the rise and contested nature of the term itself, ch.10).
} 
${ }^{2}$ More generally, the musicological comfort with the term Hindustani is also revealing, generally referring to a contrast in the South Asian context within the "classical" tradition and against Carnatic forms, and markedly less concerned with questions of language and register.

${ }^{3}$ David Lelyveld (2002) has discussed important exceptions to this relative lack of commentary particularly of note are the critics Baburao Patel, who advocated for a simple "Hindustani" in films, and Ravi Shankar Shukla, whose many interventions on language in broadcast media included a disdain for Hindustani in Hindu mythologicals.

${ }^{4}$ To the extent that scholars have considered the question of language itself, they have done so only briefly. Mukul Kesavan has argued that the language of Hindi film is in fact Urdu, and that Urdu along with other Islamicate tropes - here Awadh and the tawa'if-have constituted or inspired the "architecture" of Hindi cinema (Kesavan, 1994). This position has been emphatically rejected by Harish Trivedi, who argues instead for "all kinds of Hindi", while remaining deeply suspicious of the term "Hindustani", the use of which he suggests is "to walk more than half way down the path" to Urdu (Trivedi, 2006). Both approaches remain inadequate to describing and accounting for the choices made, proactively, by writers and lyricists themselves operating as agents within a wide horizon of linguistic and artistic possibilities. The tendency to locate agency, limits, and capabilities in the languages/registers themselves (e.g. Trivedi's remark that "the high Urdu" of the opening scene's of Mughal-e Azam "needs to be inflected with a contextually apt Sanskritic phrase" [65]) typifies this approach. I thus use Hindustani as a non-, or perhaps anti-ideological signifier of expansive linguistic possibilities, and focus on the opportunities that film afforded writers to not make explicit ideological choices.

${ }^{5}$ The screenplay was based on a story by Hayatullah Ansari, itself based on Maxim Gorky's 1902 play На дне (The Lower Depths), an unredemptive depiction of Russian peasants in a shelter for the homeless (Rajadhyaksha and Willemen, 1999; 306).

${ }^{6}$ Reflecting, in some sense, the participation of Abbas at the nexus of the Hindi, Urdu and English literary worlds. See Gopal, 2005; 128 (though Neecha Nagar is conspicuously absent from Gopal's analysis of Abbas' work).

${ }^{7} R \bar{a}$ 'nāizyāin, for example, had its first edition in 1944 (Delhi: Kutub Khana Azizia) before a second edition in 1950 (Bombay: Taj Office), and subsequent editions in the 1960s and 70s, followed by its incorporation into various editions of his collected works.

${ }^{8}$ I maintain a useful, albeit somewhat artificial, distinction here between lyric and poem here, for the sake of convenience only.

${ }^{9}$ The first line of the śer is slightly modified from the published version, which reads Vahī kārvān vahī rāste vahī zindagì vahì marhalle. The film version moves zindagi to the front of the line, emphasising the echo effect to the song lyrics. (Badayuni, n.d.).

${ }^{10}$ The lyric is reminiscent of a common Hindi phrase, describing this world or life as "cār din kā melä" or a four-day fair. It is a phrase found in Kabir's poetry, as well as a variety of song recordings (occasionally as "do din kā melä", or a two-day fair).

${ }^{11}$ Consider, for example, the following couplets: "Merā kufr hạssil-e zūd hai merā zūd hâssil-e kufr hai / merī bandagī vo hai bandagī jo rahìm-e daur-o haram nahīm”, and “ Mujhe rās à'e khudā kare yahī iśtibāh kī sā 'atem / unhem aitbār-e vafā to hai mujhe aitbār-e sitam nahìm"." (Badayuni,n.d.)

${ }^{12}$ See, for instance, Muhammad Sadiq's condemnation of Abdul Hayee 'Sahir' Ludhianvi in his history of Urdu literature (Sadiq, 1984).

${ }^{13}$ This is not to suggest, however, that Urdu poetic genres such as the ghazal have been seamlessly integrated into the world and language of films. Naseem Hines has noted the ways in which Ghalib's poetry was denuded of its mystical elements through a process of "romanticisation" in two postindependence productions (Hines, 2007). The transformations that Sahir Ludhianvi wrought on his nazm 'Cākle' to prepare it for inclusion in Guru Dutt's 1957 film Pyaasa are also worth noting.

${ }^{14}$ The idea of separate realms of literary endeavour was recognised and expanded upon by Sahir Ludhianvi in 1974 who, in the introduction to a collection of his film lyrics, addressed himself explicitly to his literary critics, defending the lyricist from accusations that the form was somehow less than the formal literary product. He remarked on the reach of the lyric, its potential for inspiration and to act as a vehicle for national progress (samāji taraqqu) , while drawing critics' attention to the relative lack of freedom and the many restrictions ( $p \bar{a} b a n d \bar{l})$ under which the lyricist laboured, and asserting his own efforts to bring the lyric as close as was possible to classical/creative poetry (takhlīqu śa 'iri) (Ludhianvi, 1974; 11-3).

${ }^{15}$ This is not to say that the issue of script, or written language more broadly, was entirely absent during the silent period. One critic bemoaned the poor quality of titles as prepared for the silent films, and the irregularities in quality between titles prepared in various languages, while asserting the need 
for higher production standards particularly with regard to Hindi titles. He wrote, regarding the 1931 production Devi Chowdhurani, "The lack of Hindi language [intertitles] in such a popular film was really disappointing to many admirers of Bankimchandra's works who are unfortunately incapable of understanding English and Bengali titles...It is expected that the producers will not ignore a language which is treated as the lingua franca of India." (Mehra, 1931).

${ }^{16}$ For an earlier, fictional representation of the movie theatre as a space of moral laxity, see Ugra, 1924. Such a satirical depiction as Ugra's may well have been intended as a response to the not uncommon sense of unease that the cinema hall generated, especially as a desegregated space. See, for a prominent example, Gandhi's own views on the subject: “...I have never been to a cinema. But even to an outsider, the evil that it has done and is doing is patent." Statement to the Indian Cinematograph Committee 1927-28, quoted in Dwyer, 2011.

${ }^{17}$ This is not to suggest that only Muslims would have been able to read the quotation: a sizeable number of Hindus, particularly in the Punjab and United Provinces, were literate in Urdu in this period (though the demographics were already shifting. The point, however, is to focus on orality/aurality versus literacy in the context of the medium and languages choices. It is also not to say that long passages of English would not have alienated certain sections of a 1940s film audience in a similar way; however, this latter alienation would have been predominantly class-based, and is of little relevance in the context of the Hindi-Urdu debate.

${ }^{18}$ Roman script was also used for the brief textual intervention in Nek Pervin, when the names of the various cities that Parveen's husband visits in pursuit of his gambling flash up on the screen over rolling railway tracks.

${ }^{19}$ Issues consulted here were published between 1941-45.

${ }^{20}$ It also adds weight to Heidi Pauwels' contention that devotional films should not be dismissed as either "simple expressions of popular devotion" or as "manipulation of presumably illiterate masses"; rather, these were commercial products like any other (Pauwels, 2007).

${ }^{21}$ The inclusion in several of the adverts discussed of the names of specific cinema halls suggests the involvement of exhibitors in at least some of the film marketing, and opens up the possibility of examining region-specific approaches to advertising. The dynamics of such variations are, regrettably, outside the scope of this discussion. However, it seem likely that fruitful insights could be gained through an examination of the languages of advertising in other urban settings, such as Bombay, Calcutta and Lahore, in particular, and of other languages e.g. Gujarati, Marathi and Bengali. 